\title{
Буріння свердловин
}

УДК 622.24

DOI: 10.31471/2304-7399-2018-2(46)-191-196

\section{БУРІННЯ НАФТОВИХ І ГАЗОВИХ СВЕРДЛОВИН: ВЧОРА, СЬОГОДНІ, ЗАВТРА}

\author{
P. С. Яремійчук \\ м. Львiв; e-mail:R.B.jarem@gmail.com
}

У статті йдеться про розвиток технологій буріння свердловин впродовж останніх 150 років. Проаналізовано роторне буріння та буріння турбобурами, електробурами, гвинтовими двигунами.

На думку автора проекти буріння експлуатаційних свердловин повинні складатись з двох частин, перша з яких забезпечує максимально можливу швидкість буріння, а друга - належне розкриття продуктивних пластів.

При реалізації першої та другої частин проекту рекомендується використовувати сервісну систему виконання окремих видів робіт із залученням фахівиів відповідного профілю. Це стосується, в першу чергу, регулювання властивості промивальних рідин, режимів їх цииркуляиії у свердловині, а також процесів кріплення стінок свердловини. Сервісні компанії, на думку автора, також повинні залучатися до усіх видів відновлення фільтрачійних характеристик пластів-колекторів.

Ключові слова: буріння свердловин, роторне буріння, турбобур, електробур, вибійний двигун, регулювання властивостей промивальних рідин, ежекторний пристрій, відновлення фільтраиійних властивостей пластів-колекторів.

Буріння нафтових і газових свердловин є однією 3 надзвичайно складних технологій, які постійно розвиваються впродовж півтори сотні років. Змінювалися способи буріння від ударного руйнування порід до руйнування порід різними типами бурових доліт з використанням їх обертання на вибої бурильними трубами (роторне буріння) або з використанням вибійних двигунів (турбобурів, електробурів, гвинтових ). У тридцяті - вісімдесяті роки минулого століття в колишньому СРСР в технологіях спорудження свердловин переважало турбінне буріння. Цьому сприяло і те, що створення турбобурів базувалося на теоретичних засадах П. Шумилова та роботах видатних вчених-конструкторів Р.

ISSN 2304-7399. Прикарпатський вісник НТШ. Число. - 2018. - № 2(46) 
Іоаннесяна, М. Гусмана, М. Тагієва, Г. Булаха та інших, а також те, що перед другою світовою війною і в наступні десятиліття були відкриті потужні нафтові родовища між Волгою та Уралом, що залягали на глибині від 1200 до 2000 метрів. Саме на цих глибинах турбінне буріння дозволило швидкими темпами нарощувати видобування нафти в умовах другої світової війни з використанням тодішніх бурильних труб і радянських шарошкових доліт.

У тридцятих роках минулого століття в Харкові починається розробка електробурів з підведенням кабелем через бурильні труби змінного струму під високою напругою. В $70-\mathrm{x}$ роках минулого століття там же створюються телеметричні системи для буріння свердловин електробурами, що дозволило почати роботи зі спорудження похило скерованих і горизонтально-розгалужених свердловин цією технікою. На той час ця техніка і технології не поступались зарубіжним аналогам.

Необхідність буріння свердловин на значно більші глибини ( від 3000 до 6000 і більше метрів) показало значно меншу ефективність турбінного буріння у порівнянні з роторним способом.

У $60-$ р роки минулого століття майже одночасно починаються роботи з конструювання гвинтових об'ємних двигунів у Франції, США і СРСР. Дещо пізніше почалося конструювання електробурів на постійному струмі у США та Україні, але ці роботи у нас не знайшли подальшого розвитку, позаяк тодішне керівництво нафтогазової промисловості не підтримало розвиток цього перспективного способу буріння навіть у надглибоких свердловинах.

У другій половині 20 -го століття в Україні буровими підприємствами Міністерств геології, нафтової і газової промисловостей виконується великий обсяг розвідувальних робіт, відкриваються та вводяться в розробку потужні нафтові і газові родовища на суші та в шельфовій зоні Чорного та в акваторії Азовського морів. Видобуток газу сягає 68 млрд. кубічних метрів та нафти 15 млн тонн за рік. Буровими колективами сходу і заходу України освоюється буріння глибоких та надглибоких свердловин ( Луги -1, Синьовидне -1 з глибиною 6500 м і 7000 м та Шевченкове -1 глибиною 7522м). На Долинському та СтароСамбірському нафтових родовищах успішно пробурено електробурами 3 використанням телесистем одинадцять розгалужено-горизонтальних свердловин, що могло стати прообразом в майбутньому буріння горизонтальних свердловин. В Прикарпатті здійснено буріння більше сорока свердловин з продувкою вибою стиснутим повітрям, природним газом, азотом та бурінням на аерованих бурових розчинах. При бурінні стовбурів великого діаметра широко застосовуються реактивнотурбінні бури та суміщений турбінно-роторний способи. Виконані геолого-розвідувальні роботи підтверджують наявність великих ресурсів нафти і газу в надрах Дніпрово-Донецької западини, на Прикарпатті, Волино-Поділлі та на Чорному і Азовському морях.

ISSN 2304-7399. Прикарпатський вісник НТШ. Число. - 2018. - № 2(46) 
3 відкриттям потужних нафтових і газових родовищ у Західному Сибіру припиняється фінансування бурових робіт в Україні, а бурові організації спрямовуються разом з буровими верстатами для роботи в Сибіру. Величезний ріст видобування нафти і газу в СРСР наприкінці 20 століття значною мірою забезпечився за рахунок бурових робіт українських організацій.

В Україні були розроблені під керівництвом П. Ф. Шпака та затверджені урядом дві державні програми нарощування видобування нафти і газу на суші та одна для Чорного і Азовського морів, реалізація яких уже в 2010 році робила би Україну енергонезалежною ( передбачалося видобувати 28 млрд. метрів кубічних газу і 5 млн. тонн нафти, без урахування їх видобутку з наших морів ). Але ці програми були профінансовані лише на 10 відсотків від необхідних розмірів і виконати їх було неможливо.

За останні двадцять років в західній частині та на сході України припинили роботи більшість бурових організацій, що призвело до втрати найголовнішого - професійних, з великим досвідом інженерів та робітників. Практично припинили свою роботу геолого-розвідувальні НДІ та експедиції.

Сьогодні в Україні почався процес відновлення геологорозвідувального і експлуатаційного буріння свердловин. Урядовими заявами прогнозується за п'ять наступних років досягти енергетичної незалежності України. При цьому передбачається залучення до цих робіт не лише державних, але і приватних компаній.

Проте цей процес нарощування власного видобування нафти і газу йде дуже повільно. Причин цього дуже багато. Для розширення обсягів буріння свердловин необхідно вкласти великі кошти для придбання сучасного бурового обладнання, в основному, виробництва США, Сінгапуру або інших західних компаній. В Україні нема власного виробництва сучасних бурових доліт, бурильних та обсадних труб, іншого бурового інструмента і починати освоєння їх заново недоречно.

Важливим є освоєння сучасних технологій буріння свердловин, особливо глибоких і надглибоких, українськими буровиками. Ці технології базуються на отриманні бурильником (оператором) багатофакторної інформації про взаємодію бурового долота з породою, про характер гідродинамічних тисків на вибої та на стінках свердловини при спускопідійманні бурильних труб та в процесі самого буріння свердловини, про механічні, фізичні і колекторські властивості порід при їх розбурюванні. Професійні якості бурильника визначаються його вмінням виконувати буровий процес, керуючись інформацією, що поступає зі свердловини. На жаль, наші спеціалісти не вміють працювати 3 новими комп'ютерними програмами в реальному буровому процесі, що підтвердилося при бурінні свердловин з так званих «вишок Бойка» сінгапурського виробництва в Чорному морі на Одеському газоконденсатному

ISSN 2304-7399. Прикарпатський вісник НТШ. Число. - 2018. - № 2(46) 
родовищі. Ці складні системи були відключені і буріння здійснювалося за старими ще з радянських часів схемами. Внаслідок цього ефективність роботи наших спеціалістів залишилася на попередньому низькому рівні. В наших університетах Івано-Франківська, Полтави і Харкова цьому навчити нікому, бо ними не володіють і викладачі фахових кафедр.

Проекти буріння, зокрема експлуатаційних свердловин, носять схематичний характер і призначені, в основному, для оцінки вартості їх спорудження.

На наш погляд, ці проекти повинні мати дві складові:

1. Перша частина проекту повинна забезпечувати максимально можливу швидкість буріння від початку її забурювання до досягнення покрівлі продуктивних пластів. Цієї мети можна досягти при науковообгрунтованій конструкції свердловини, використанні сучасних досконалих бурових доліт, способу їх обертання, реалізації режимів буріння на основі комп'ютерного опрацювання інформації з свердловини, застосуванні сучасних типів промивальних рідин і регулюванні їх властивостей хімічними реагентами в залежності від властивостей гірських рід.

2. Друга частина проекту повинна бути присвяченню конструкції вибою свердловини, технології розкриття продуктивних пластів, технології відновлення погіршених в процесі розкриття їх фільтраційних характеристик, технологіям виклику припливу, закінченню освоєння свердловини і передачі ії в експлуатацію. Всі відомі і доступні методи відновлення або навіть покращення фільтраційних характеристик пластаколектора повинні бути закладені в цю частину проекта і повинні мати фінансову оцінку.

В Україні значна частина перспективних родовищ нафти і газу розміщена в пластах з аномально низькими пластовими тисками. Ці родовища знаходяться на теренах Дніпрово-Донецької западини, на Волино-Подільській платформі та в родовищах, що розробляються впродовж тривалого часу. Розкриття продуктивних пластів повинно виконуватися на аерованих бурових розчинах з постійним контролем тисків при виконанні спуско-підіймальних робіт та під час їх розкриття бурінням. Для цих пластів повинні розроблятися і спеціальні методи відновлення проникності в процесі освоєння свердловин.

При реалізації першої і другої частин проекту варто використовувати сервісну систему виконання окремих видів робіт з залученням фахівців 3 цих робіт. В першу чергу це стосується регулювання властивостей промивальних рідин, режимів їх циркуляції у свердловині, а також процесів кріплення свердловини. Сервісні компанії повинні залучатися до всіх видів відновлення фільтраційних характеристик пластів-колекторів.

Сьогодні в Україні практично припинено фінансування науково дослідних робіт з удосконалення процесів руйнування порід під час буріння. Але, для прикладу, отриманий в минулі роки досвід показав, що буріння в умовах суттєвого зменшення тиску промивальної рідини на

ISSN 2304-7399. Прикарпатський вісник НТШ. Число. - 2018. - № 2(46) 
вибої при продувці вибою газами або аерованими рідинами збільшує проходку на долото і швидкість буріння в $3-5$ і навіть в десять разів. Цей спосіб буріння можна застосовувати лише при проходці гірських порід, які не руйнуються за відсутності тиску на стінках свердловини. Проте досягнення цих результатів можна отримати іншим способом. В 2003-му році в Івано-Франківському національному технічному університеті нафти i газу була захищена кандидатська дисертація Я. В. Фем'яком, в якій тиск на вибої в процесі руйнування порід долотом знижувався за допомогою ежекторного пристрою, встановленою над долотом. При такому бурінні стінки свердловини знаходяться під необхідним тиском промивальної рідини, а руйнування породи відбувається за суттєвого зниження тиску рідини на вибої. Промислові випробування цієї технології показали збільшення проходки і швидкості буріння в 3.5 і 4.5 разів відповідно. На жаль, в силу багатьох причин ця технологія не була підтримана керівництвом галузі і їі подальший розвиток зупинився. На наш погляд, сьогодні треба було би виготовити декілька цих наддолотних пристроїв та провести повторно ці експериментальні роботи на бурових, а після їх удосконалення реальні бурові роботи виконувати сервісною компанією. При широкому застосуванні цього наддолотного обладнання та технологій можна скоротити час спорудження свердловин до двох разів, а це може суттєво зменшити вартість буріння свердловин.

Це лише один з прикладів не реалізованих наукових досліджень в практиці буріння свердловин.

В минулому 2018 році опубліковано монографію «Освоєння нафтових і газових свердловин. Наука і практика» (автори Булатов А. Ш., Качмар Ю. Д., Савенок О. В., Яремійчук Р. С.), в якій згруповано дослідження останніх десяти років в цій частині спорудження свердловин. На жаль, вона вийшла невеликим тиражем (250 примірників) i швидко розійшлася. I ще більше жаль, що в наших фахових університетах ця частина професійних знань не доходить до майбутніх спеціалістів. Головним в цій книзі є обгрунтування за геологічних умов за яких рекомендується застосування тих чи інших методів покращення або відновлення фільтраційних властивостей пластів-колекторів та детально описані самі технології. До них відносяться хімічні методи впливу на пласт, звичайний та потужний гідророзриви пласта, методи впливу на привибійну зону пласта шляхом створення багаторазових депресій і репресій та методи оцінки фільтраційних властивостей порід у процесі освоєння свердловин.

Особливу роль у підвищенні ефективності спорудження свердловин на сьогоднішній час могло би відігравати широке застосування колтюбінгових технологій при розкритті багатопластових колекторів 3 різними фільтраційними характеристиками. Ці технології знайшли значне застосування в практиці спорудження свердловин у США та інших

ISSN 2304-7399. Прикарпатський вісник НТШ. Число. - 2018. - № 2(46) 
країнах світу. В Україні вони ще не знайшли свого належного застосування. У нашій монографії «Колтюбінг в нафтогазовидобуванні» (автори М. М. Поліник, В. М. Ясюк, Р. С. Яремійчук, 2014 р., в-во «Центр Європи») описані обладнання та технології, що застосовуються в багатьох країнах світу і дозволяють не лише збільшити продуктивність свердловин, зменшити їх кількість, але і суттєво покращити розробку родовищ.

Нам видається, що досягти порівняно швидкого збільшення власного нафто- і газовидобування треба шляхом широкого залучення до буріння свердловин і розробки родовищ приватних і зарубіжних компаній. Але при цьому треба було би суттєво зменшити оподаткування виконуваних бурових робіт, кардинально спростити відведення земель та вирішити на державному рівні ряд інших проблем.

Реалізація багатьох пропозицій науковців, проектантів і практиків дозволить збільшити видобування власних нафти і газу до необхідних величин.

Стаття надійшла до редакиійної колегії 13.12.2018 p. Рекомендовано до друку д.т.н., професором Мойсишиним В.М. д.т.н., професором Кунцяком Я.В. (м. Київ)

\title{
DRILLING OF OIL AND GAS BORE: YESTERDAY, TODAY, TOMORROW
}

\author{
R. S. Yaremiychuk \\ Lviv; e-mail:R.B.jarem@gmail.com
}

The article deals with development of bore drilling technologies over the past 150 years. Rotor drilling and drilling with turbo booms, electric drills, screw engines are analyzed.

According to the author drilling operations of bores should consist of two parts the first of which provides maximum possible drilling speed, and the second - the proper disclosure of productive strata.

When implementing the first and second parts of the project it is recommended to use service system for the implementation of certain types of work with the involvement of specialists of the profile. This applies in the first place to the regulation of the properties of washing liquids, the modes of their circulation in the well, and also the processes of fixing the walls of the well. According to the author service companies should also be involved in all types of recovery of filtration characteristics of reservoir layers.

Key words: drilling of bores, rotor drilling, turboprop, electric drill, knock-out engine, regulation of properties of washer liquids, ejector device, restoration of filtration properties of reservoir layers. 